\title{
Political Communication: A Case Study of Joko Widodo - Ma'ruf Amin Victory in the 2019 Indonesian Presidential Election
}

\begin{abstract}
Sutrisno $^{1}$, Taufik ${ }^{2}$, ${ }^{1}$ Department of Communications Science, Faculty of Social and Political Sciences, Universitas Pasundan Bandung, ${ }^{2}$ Correspondent Author; $\mathrm{PhD}$. Student of Political Science, Faculty of Social Science and Humanities, Universiti Kebangsaan Malaysia; Department of International Relations, Faculty of Social and Political Sciences, Universitas Pasundan Bandung. Email: ${ }^{1}$ Sutrisno@unpas.ac.id ${ }^{2}$ Taufik@unpas.ac.id
\end{abstract}

Indonesia's fourth presidential and vice-presidential election will be held post-reform. Indonesia's success in carrying out direct elections by the people after the reform became a history for Indonesia and world democracy. As the only democratic country in the world with ethnic, religious and cultural diversity, Indonesia means every elite or candidate, both legislative and President, must understand the characteristics of the voters very well. So, sometimes the presidential candidates who will lead Indonesia need extra energy to understand the characteristics of the people in each region. Even in winning elections, each candidate has a different style and way of communicating politics, and they have a unique strategy in communicating. Symbolic communication is not infrequently used to get attention and get maximum votes when voting. However, every election is always coloured by the spread of hoax news and information to gain the people's attention and voice. In the 2019 presidential election, incumbent candidate Joko Widodo chose K.H Ma'ruf Amin as a companion and who was also considered appropriate for winning. This research uses qualitative methods and phenomenology as a tool of analysis; this article seeks to discuss and discover the communication style used by the Jokowi - Ma'ruf couple to win the 2019 presidential election.

Keywords: Indonesian Presidential Election 2019; Jokowi-Ma'ruf; Political Communication; Political Communication Style; Symbolic Interaction 


\section{INTRODUCTION}

Post-1998 reform, Indonesia has conducted direct presidential and vice-presidential elections four times, namely in 2004, 2010, 2014 and 2019. The 2019 Presidential Election was attended by two pairs of presidential and vice-presidential candidates. Interestingly, each presidential candidate was an older player who was also a rival in the previous presidential election.

The presidential candidates are a group that has been involved in Indonesian politics during the New Order era, such as Jokowi. He was included in the circle of the Indonesian Democratic Party of Struggle (PDI-P) led by Megawati, Indonesia's first President, Sukarno, and Prabowo, who is the son-in-law of President Soeharto. In addition, in several elections that have resulted in polarised in Indonesia, Indonesia has become increasingly divided, both in the 2014 presidential election, the 2017 DKI Jakarta gubernatorial election and the 2019 presidential election (Warburton 2018, 25). Even in the political support of Jokowi and Prabawo, it was caused because the two figures were populist figures, in which Jokowi is known as a populist technocrat. In contrast, Prabowo is known as an ultra-populist (Mietzner 2015).

Jokowi's candidacy was promoted by the PDI-P together with the pluralist coalition. Prabawo exploited the vulnerability of pluralist themes by joining and allying with Islamic parties, Islamic figures and hard-line Muslim groups (Warburton 2018, 25-26). Even in the 2014 presidential election, there were many issues to overthrow Jokowi. Such as Jokowi is a nonMuslim Jokowi, subject about Jokowi being a communist, etc. In addition, in the 2017 DKI gubernatorial election, Basuki Tjahaja Purnama (known as Ahok), Christian and ethnically Chinese, allied with Jokowi's group and faced stiff opposition Islamic groups supporting Anis Baswedan, who had a coalition with Prabowo. This issue is increasingly coming to the public's attention due to Ahok's speech on the Thousand Islands, which is considered insulting Islam. Even the case of SARA (ethnicity, religion, race and class) that always appears in Indonesian politics is regarded as a regression to democracy in Indonesia (Hadiz 2017; Warburton 2018).

However, what is interesting about the 2019 presidential election is that it still carries Jokowi as an incumbent (technocrat-populist) and Prabowo (ultra-populist). In a situation and conditions of worsening polarisation, Jokowi withdrew KH Ma'ruf Amin as a candidate for Vice President from Islamic circles, Rais Am Central Board of Nahdatul Ulama (PBNU) as well as the General Chair of the Indonesian Ulema Council (MUI). Despite this, polarisation continued until and, in the end, Jokowi-Ma'ruf won. Nevertheless, Jokowi-Ma'ruf still had to work hard to win the 2019 Presidential Election. Thus, active political communication is needed to be accepted by all groups of people in Indonesia. This article tries to analyse the political communication used by Jokowi-Ma'ruf in the Presidential Election 2019. 


\section{CONCEPTUAL FRAMEWORK}

\section{Indonesian Presidential Election}

After the reform in 1998, the general election system in Indonesia underwent significant changes. After the amendment of the Constitution (UUD) 1945 in article 6A. The election of President and Vice President in Indonesia has changed from indirect to direct election by the people. Of course, it is very different from before the amendment, which mandated the People's Representative Assembly (MPR) as determining the President and Vice President. As a result, as a post-reform democratic party in 2004, Indonesia held the presidential election for the first time, and it has been held four times. In 2004, 2009 and 2014 presidential elections, the presidential elections were held after the legislative elections. The pairs of candidates for President and Vice President are promoted by political parties or coalitions of political parties participating in the general elections before implementing the general elections. The pairs of candidates for President and Vice President, who obtain votes of more than fifty per cent of the total votes in the general election - with at least twenty per cent of the votes - in each province spread over more than half of the number of provinces in Indonesia. It can be appointed as President and Vice President.

Whereas in 2019, the presidential election was held simultaneously with the legislative elections. This simultaneous election scheme results from a Judicial Review of Law Number 42 of 2008, which was filed by Effendi Ghazali and the Coalition civil society for Elections sued to the Constitutional Court (MK) in April 2014 (Budiatri, Noor, and Romli 2018, 1). The Constitutional Court considered the Election Law's inconsistency, especially on 12, 14 and 112, which stipulated the post-legislative presidential election. With the Constitution 1945, Article 6A paragraph 2 and Article 22E paragraph 2 which stated that the presidential and vicepresidential candidate pairs were announced before the election, and the election was defined as legislative and the presidential elections which were simultaneously (Budiatri, Noor, and Romli 2018, 1-2; Indarja 2018).

On the other hand, the implementation of simultaneous elections is expected to create a coalition of supporters of the presidential election candidates to be more ideological and based on a common goal. In which, the implementation of the Presidential Threshold based on the previous legislative elections has become a trap for political parties in the vortex of a transactional coalition in carrying the presidential candidacy and has the potential to produce a single candidate in the election (Budiatri, Noor, and Romli 2018, 2-3).

\section{Symbolic Interaction}

Political communication study is the study of political activities that are inclined more towards practical political movements such as campaigns, elections, etc. In a political context, many scholars place political communication as an essential component in practical politics. Political 
communication can be understood as a public discussion on allocating public resources and official authority (Junaedi 2013, 24). According to Doris Graber, quoted by Brian McNair (2011, 2-3), political communication as a political language compromises rhetoric and paralinguistic signs such as gestures and political actions such as boycotts and protests. Political communication performed by Jokowi-Ma'ruf has its meaning. The communication performed by both of them was functional in providing information and socialising programs to the public once they were elected as the President and Vice-President of Republic Indonesia.

To study the phenomenon of the success of political communication carried out by JokowiMa'ruf, the writer uses a symbolic interaction approach. Symbolic interaction is an approach that focuses on the results of 'interpretation' to subjective meanings that originate from the human interaction. In symbolic interactions, a person's response does not only come from reactions to the actions of others but rather is based on meaning from the use of interpreted symbols. Thus, the communication process is established when an individual understands, evaluates and gives sense to something. Herbert Blumer (1952), cited by Bachtiar (2006), stated that symbolic interactions contain basic ideas: First, interacted community activities correspond through joint action; Secondly, the interaction that occurs is a human activity; Third, the object does not have intrinsic meaning. The thing is divided into three: physical, social and abstract; Fourth, each individual sees himself as an object; Fifth, individual actions are interpretative actions that they make by themselves; Sixth, each action is interrelated and adjusted by group members. Each action is joint action and repeatedly performed (Bachtiar 2006, 249-50). According to Julian Wood, symbolic interaction is a process where humans interact with symbols to build meaning. Through these symbolic interactions, we can get information and ideas, understand our own experiences and the experiences of others, share feelings and get to know others (Wood 1992, 93). In this context, symbolic interactions can be understood that humans behave following the understood values in their environment. The existing values are not accepted but are adjusted to their current understanding, which results from interactions with other people in their environment (Hikmat 2019, 159).

Symbolic interaction is influenced by social structures that shape behaviour and eventually form symbols in society. This theory emphasises that individual must be proactive, reflexive and creative in interpreting or translating each behaviour. This symbolic interaction highlights two things: human beings are inseparable from social interaction, and the interaction is in the form of dynamic symbols; on other hands, the interaction of mutual social action is an individual communication with each other to orient each other's actions (Ahmadi 2008, 311).

In this context, the symbolic interaction perspective attempts to understand how human behaviour from the subject point of view and humans acts only based on the surrounding objects' results. In this context, it can be understood that the communication behaviour or style performed by Jokowi-Ma'ruf is the communication behaviour or style which is interpreted from the results of interactions and then adjusted to the environment, objects or targeted voters. The symbols used by Jokowi-Ma'ruf are precisely contemporary patterns resulting from current 
development and socio-political dynamics that occurred in Indonesia. On the other hand, Jokow-Ma'ruf is demanded to be more proactive in interacting with the community, both in social media or blusukan. ${ }^{1}$

\section{RESEARCH METHODS}

In this research, the authors are using a qualitative research method with phenomenology. The qualitative research method emphasises the analysis of the dynamics of the relationship between phenomena observed using scientific logic (Azwar 2015, 30). In this context, authors use phenomenology research, where phenomenology explains the meaning of the concept or phenomena of experience based on the consciousness that occurs in some individuals. Phenomenology views a communication problem developing in gaps in various subjective points of view. Phenomenology comes from Greek, namely, phinesthai, which means "what is seen", and logos which means knowledge (Morrisan 2013, 38).

Richard L. Laningan, in his article entitled 'The Phenomenology of Human Communications as a Rhetorical Ethic', introduces that phenomenology as a movement in the history of philosophy. And put goals and direction in theory and praxis, which is called conscious experiences, such as the relationship between humans and the place where they live. On the other hand, Laningan also mentions phenomenology as a theory that emphasises itself with the nature and function of consciousness (Laningan 1979, 5).

Phenomenology traditions assume that people actively interpret experiences and try to understand the world with their personal experiences. Then, Standley Deetz concluded there are three basics of principles of phenomenology: First, knowledge is found directly in conscious experience; Second, the meaning of objects consists of the power object in a person's life; Third, assumption that language is a vehicle of meaning (Littlejohn, Foss, and Oetzel 2017, 111)

In this context, the authors tried to seek data by looking at phenomena that occurred in certain moments with the political elite and also see the reality when Jokowi and Ma'ruf Amin campaigned to attract voters. The phenomenon is certainly interesting because this candidate used the method. The technique has been commonly done in Indonesia, but it looked more effective for Jokowi-Ma'ruf Amin.

On the other hand, in data collection, this paper uses participating observer and archival studies. The authors try to observe the presidential candidate pairs by looking at the national media reporting about the candidate's campaign and related documents. Then, the authors are also a

\footnotetext{
${ }^{1}$ Blusukan comes from the Javanese language, which has been absorbed into Indonesian, which means going to certain places to find something. In this context, Jokowi-Ma'ruf blusukan by looking at the situation and condition of the community to find out the real problems that occur in a society which later can make policies that are pro-people policies. Blusukan can be translated as 'down to the people'.
} 
successful team in winning Jokowi-Ma'ruf for the West Java region. So, it is sufficient to describe how the presidential and vice-presidential candidates carried out the political communication model for the author.

\section{DISCUSSION}

Political communication plays an essential role in practical politics, attracting voters or socialising government work programs. In the 2019 presidential election, Jokowi-Ma'ruf had its model and style to attract voters from various circles, including millennials. Jokowi-Ma'ruf utilised three strategies of political communication, namely: distribution of political communications, utilisation of media, and going to ground (blusukan). First, the distribution of political communication objects. Jokowi-Ma'ruf divided communication objects into segments that were following their respective potential. Jokowi had an advantage over other candidates: he was an incumbent and had experiences in Indonesian politics. In addition, Jokowi was also a furniture entrepreneur, and with Jokowi, furniture is exported to Europe and America (Hanifah n.d.). Before he became a businessman, Jokowi was a difficult commoner living on the side of Kalianyar. Jokowi was not born from one of Java's vertical structures, so it takes time to fight marginalisation (Mas'udi and Ramadhon 2018, 125). He has fully understood the situation, conditions, and characteristics socially and economically in Indonesia. Jokowi understands the economic pace and policies necessary to improve the entrepreneur's competitiveness and people's purchasing power, including infrastructure development policy (Alberthiene Endah 2018, 148-61).

On the other hand, political communication performed by Jokowi also had three segments:

(1) Islam (santri and abangan). ${ }^{2}$ In this context, with their respective abilities and backgrounds, Jokowi-Ma'ruf had their own ability to approach the nationalist community and groups, both ethnic and religious. Jokowi conducted political communication with various community organisations, both Islam and non-Islam, to ask for advice and input for Indonesia's development. In this context, what needs to be understood is Indonesia's polarised situation and condition, especially in Islamic segments or groups (Warburton 2018). Thus, Jokowi required to approach and establish communication with Islamic groups, including major Islamic organisations such as Nahdatul Ulama and Muhammadiyah. This communication will attract sympathy towards Jokowi because they feel admitted, appreciated and needed by Jokowi.

(2) Nationalists / secular. Jokowi, also known as a nationalist/secular figure, approached political parties and nationalist/secular figures. In this context, Jokowi and Ma'ruf established

\footnotetext{
${ }^{2}$ Clifford Geertz implied that Islam santri is a type of Javanese society considered obedient and performing religious orders related to the five pillars of Islam and other doctrines. This type is Muslims that deepen Islam earnestly, such as prayer, fasting, zakat and so on, and considered a generation that will continue the ulama or Kiai. While abangan is Muslim representatives who are syncretic and magical. This Islam is domiciled in rural areas that do not comprehend the Islamic doctrines to understand Islam only in general. They claimed to be Muslims but were inconsistent in performing religious orders. This inconsistency was more due to the potent beliefs and traditions that developed a long time before the entry of Islam (Geertz 1976)
} 
communication with the supporting parties, such as PDI-P, Golkar, Nasdem, Hanura, PSI, and secular figures. The visit was Jokowi's way of communicating politics to consolidate his program in winning the battle in the presidential election. This can be demonstrated by appointing nationalist figures to be the national campaign team (TKN) consisting of national party figures and non-party notional figures, such as Eric Tohir as the head of TKN (Ini Susunan Lengkap Tim Kampanye Nasional Jokowi-Ma'ruf 2018), including visiting political parties official such as Aburizal Bakrie (Aburizal Bakrie Perkuat Dukungan Golkar Ke Jokowi 2018).

(3) The younger generation (millennial). In this context, voters in the 2019 presidential election are divided into xenial and millennial generations. The magnitude potential of millennial generations makes them a campaign target or object.

Each candidate pair had his style and communication. The most important thing to observe is the Jokowi-Ma'ruf symbolic communication style in gaining the vote of young people. Communication style was shown to the polite, polite and tend to accept any community complaints to make it so that the public quickly gives sympathy to the two pairs of this candidate, especially Jokowi. Jokowi tried to follow the current trends with a millennial-style approach, either by wearing youngsters' costumes or clothing and always appearing in a 'cool' and relaxed style (big bike, sneakers and denim jacket: rebranding Jokowi to win millennials' vote in 2019, 2018). On the other hand, with the Ulama background and once served as the Rais Aam of PBNU, Ma'ruf Amin utilises the segment on Islamic religious community by building political communication to Islamic mass organisations, Islamic boarding schools and other NU scholars (Kunjungan Ma'ruf Amin ke Pesantren Diklaim Bukan Kampanye, 2018).

The second strategy to gain voters was the media utilisation in the political activities of Jokowi Ma'ruf Amin. The use of information and technology is significant for both politicians and the government. In a democracy, media is essential for the government as a control agent to prevent arbitrariness in running the government. Also, media needed as a funnel to convey ideas and policies that have been actuated for the public interests. That's why politicians need media as well. Although politicians and the government sometimes experience friction, they often need each other. In this context, the government (politicians), the media and the community are inseparable units (Irawanto 2019).

To gain the vote of the Indonesian people, the Jokowi-Ma'ruf also utilised media and information technology according to the development and conditions of today's society (Irawanto 2019, 4). Although there are much imposing news and information about Jokowi and Ma'ruf, both of them were still relying on media, especially social media and other communication technologies. There was an effort by both of them to:

(1) To socialise the success of government work programs and achievements during Jokowi incumbency, at the same time mass mobilisation in the real and virtual worlds to support 
various programs and strategies of Jokowi in leading Indonesia. Besides that, media is also used to motivate and mobilize supporters to work together and build the nation. Jokowi extensively utilised the media to socialise his success in managing the country well by using social media such as Twitter (@jokowi), Facebook (@Presiden Joko Widodo), as well as a particular national TV program 'President Corner' on Metro TV;

(2) Countering black campaigns and hoaxes toward Jokowi's personalities and the government. Initially, Jokowi did not oppose the black campaign but conveyed the programs that had been successfully carried out by the government under Jokowi's leadership to all Indonesian people, both using mass media and social media. However, Jokowi then felt that he needed to answer various kinds of slanted issues and even rival the problems considered hoaxes or lies with the real news. Including the issues that interfere with performance and attack personalities, such as issues concerning Jokowi being Chinese, ${ }^{3}$ non-Islam, a communist and other economic issues. Which are considered to have not valid and accurate data, or there are not following the truth (Irawanto 2019, 6).

Since Jokowi was the mayor of Solo City and the Governor of DKI Jakarta, he has been a trendsetter of media coverage. Jokowi is one of the figures pursued by the media since his success in building the city of Solo. So, it is not difficult for the press to tell experiences or success stories in various ways during his leadership. In this case, many media were willing to publicise all activities and performance of Jokowi. He was considered to always pay attention to the poor both in rural and urban areas. Thus, the media support was very significant for Jokowi because Jokowi's habits and behaviour had never been carried out by previous presidents, such as a simple appearance, style of friendly speech, and always being close to the middle class and below, including blusukan (Bland 2020, 6-12).

(3) The third is the Blusukan (going to ground) method. Jokowi-Ma'ruf still applied the blusukan method or visited the community directly. This was applied based on each character and potential. These figures appealed to the community because of their different backgrounds and are considered complementary to the government. The method used was beneficial for both because it was part of establishing a proximity with the community by listening to the aspirations and desires of the community. It also provided explanations and clarification whether the people have well received the programs that have been designed and implemented or not. On the other hand, the blusukan performed by Jokowi-Ma'ruf is part of the promotion of themselves as presidential and vice-presidential candidates directly to the public.

In political communication by Jokowi and Prabowo, the two candidates used almost the same approach in establishing contact with the Indonesian people. Jokowi and Prabowo use a

\footnotetext{
${ }^{3}$ In Indonesia, the racist issue of China had occurred during the new order, until finally, President Gus Dur recognized the ethnic Chinese in Indonesia. In this context, the case of racist China is still used by elements for political purposes.
} 
symbolic system with sowan (visits) to Kiai / ulama, organisations and indigenous people to ask for their blessing and support. In social media, they raised strategic issues to create counternarratives in their campaign; in this case, both Jokowi and Prabowo used social media to campaign for their vision and mission as presidential candidates for the 2019-2024 period. However, the campaign subjectivity of each supporter occurred in a proxy war, due to competition between the incumbent and the opposition to attract mass votes. The campaign period to win votes in the presidential election also made the two candidates have to blusukan. Blusukan has been a common practice since taking office as solo mayor. However, in the constellation of the presidential election this time, both Jokowi and Prabowo made campaign visits to all corners of the country to get votes to win the presidential election. Even though the strategies were almost the same, an advantage for Jokowi is his populist character, which is simple in society and has achievements in managing the government from the mayor of Solo, DKI Jakarta, to the first term of his presidency. Meanwhile, Prabowo, although populist, is still famous for his elitist character, who has no experience as a government manager.

\section{CONCLUSION}

In the 2019 Presidential and Vice-Presidential elections, Indonesia was divided into two camps or was polarized. Polarisation occurred because those who ran as President were very populist figures, namely: Jokowi and Prabowo. Jokowi was supported by nationalist/pluralist groups, while Prabowo was supported by mass or Islamic groups. The issues developed during the campaign made the two candidates struggle to carry out various strategies to win the presidential election. In this context, one of the most important is political communication carried out by candidates, including the candidate pair Jokowi-Ma'ruf.

Political communication applied by Jokowi-Ma'ruf is interesting because they both have different backgrounds and characteristics, so it is exciting to study. At least, there were three political communication strategies carried out by Jokowi-Ma'ruf to win the 2019 Presidential Election, amid the issue of \#2019GantiPresiden and the growing black campaign, namely: the distribution of political communication objects, the use of virtual media and information technology, and the 'blusukan'. Jokowi Ma'ruf tried to establish political communication by showing the success and success of the work completed in the previous period.

On the other hand, in conducting these political communications, Jokowi-Ma'ruf Amin used symbols in interacting with voters. When they came down and voiced the voices of all levels of society, both employed and showed symbols based on community characteristics; in this context, it seems that they both cared about everyone, both religious and millennial. For example, when Jokowi visited the pesantren (boarding school), he wore a skullcap and a Muslim outfit or approached a group of bikers and took part in their touring. And what Jokowi has successfully demonstrated is that he is populist for all circles by always appearing with simplicity, which is different from Prabowo's style of communication, which tends to be elite. 
International Journal of Innovation, Creativity and Change. www.ijicc.net

Volume 15, Issue 6, 2021

\section{REFERENCES}

"Aburizal Bakrie Perkuat Dukungan Golkar Ke Jokowi." 2018. Tempo.co. https://koran.tempo.co/read/nasional/435877/aburizal-bakrie-perkuat-dukungan-golkarke-jokowi.

Ahmadi, Dadi. 2008. "Interaksi Simbolik: Suatu Pengantar.” Mediator 9(2): 301-16.

Alberthiene Endah. 2018. Jokowi: Мenuju Cahaya. Solo: Tiga Serangkai.

Azwar, Saifuddin. 2015. Metode Penelitian. Yogyakarta: Pustaka Pelajar.

Bachtiar, Wardi. 2006. Sosiologi Klasik. Bandung: Remaja Rosdakarya.

"Big Bike, Sneakers and Denim Jacket: Rebranding Jokowi to Win Millennials' Vote in 2019." 2018. The Conversation. https://theconversation.com/big-bike-sneakers-and-denimjacket-rebranding-jokowi-to-win-millennials-vote-in-2019-94890.

Bland, Ben. 2020. Man of Contradictions: Joko Widodo and the struggle to remake Indonesia About the Book. Sydney: Lowy Institute.

Budiatri, Aisah Putri, Firman Noor, and Lili Romli. 2018. Penyelenggaraan Dan Sistem Pemilu Presiden: Kecenderungan Kandidasi Dan Koalisi Dalam Pemilu Presiden 2019. Jakarta.

Geertz, Clifford. 1976. The Religion of Java. Chicago: The University of Chicago Press.

Hadiz, Vedi R. 2017. "Indonesia's Year of Democratic Setbacks: Towards a New Phase of Deepening Illiberalism?" Bulletin of Indonesian Economic Studies 53(3): 261-78.

Hanifah, Syifa. "Perjalanan Panjang Bisnis Mebel Jokowi, Akhirnya Bisa Mendunia." Merdeka.com. https://www.merdeka.com/uang/perjalanan-panjang-bisnis-mebeljokowi-akhirnya-bisa-mendunia.html?page $=4$.

Hikmat, Mahi M. 2019. Komunikasi Politik Dalam Pilkada Langsung: Teori Dan Praktik. Bandung: Simbiosa Rekatama Media.

Indarja. 2018. "PERKEMBANGAN PEMILIHAN PRESIDEN DAN WAKIL PRESIDEN DI INDONESIA.” Masalah - Masalah Hukum 47(1): 63-70. https://ejournal.undip.ac.id/index.php/mmh/article/download/17006/13377.

"Ini Susunan Lengkap Tim Kampanye Nasional Jokowi-Ma'ruf." 2018. Liputan6.com. https://www.liputan6.com/pilpres/read/3639873/ini-susunan-lengkap-tim-kampanyenasional-jokowi-maruf.

Irawanto, Budi. 2019. Perspective Making It Personal: The Campaign Battle on Social Media in Indonesia's 2019 Presidential Election.

Junaedi, Fajar. 2013. Komunikasi Politik: Teori Aplikasi Dan Strategi Di Indonesia. Yogyakarta: Buku Litera.

“Kunjungan Ma'ruf Amin Ke Pesantren Diklaim Bukan Kampanye.” 2018. CNN Indonesia. https://www.cnnindonesia.com/nasional/20180928191012-32-334094/kunjunganmaruf-amin-ke-pesantren-diklaim-bukan-kampanye/.

Laningan, Richard L. 1979. "The Phenomenology of Human Communication." Philosphy Today 23(1): 3-15.

Littlejohn, Stephen W., Karen A. Foss, and John G. Oetzel. 2017. Theories of Human Communication. Seventh. Long Grove, Illinois: Waveland Press, Inc. 
Mas'udi, Wawan, and Akhmad Ramadhon. 2018. Jokowi: Dari Bantaran Kalianyar Ke Istana - Mobilitas Vertikal Keluarga Jawa. Jakarta: PT Gramedia Pustaka Utama.

McNair, Brian. 2011. AN INTRODUCTION TO POLITICAL COMMUNICATION. Fifth. New York, NY: Routledge.

Mietzner, Marcus. 2015. Reinventing Asian Populism: Jokowi's Rise, Democracy, and Political Contestation in Indonesia. Honolulu: East-West Center.

Morrisan. 2013. Teori Komunikasi Individu Hingga Massa. Jakarta: Kencana Predana Media Group.

Warburton, Eve. 2018. "Deepening Polarization and Democratic Decline in Indonesia." In Political Polarization in South and Southeast Asia: Old Divisions, New Dangers, eds. THOMAS CAROTHERS and ANDREW O'DONOHUE. Carnagie Endowment for International Peace, $25-40$. https://carnegieendowment.org/files/Political_Polarization_RPT_FINAL1.pdf (February 24, 2021).

Wood, Julian. 1992. Spinning the Symbolic Web: Human Communication as Symbolic Interaction. Norwood, NJ: Ablex Publishing. 